\title{
Sandrine Berthelot, L'esthétique de la dérision dans les romans de la période réaliste en France (1850-1870)
}

\section{Cecilia Torelli}

\section{(2) OpenEdition}

1 Journals

\section{Edizione digitale}

URL: http://journals.openedition.org/studifrancesi/30637

DOI: $10.4000 /$ studifrancesi.30637

ISSN: 2421-5856

\section{Editore}

Rosenberg \& Sellier

\section{Edizione cartacea}

Data di pubblicazione: 1 avril 2006

Paginazione: 185-186

ISSN: 0039-2944

\section{Notizia bibliografica digitale}

Cecilia Torelli, «Sandrine Berthelot, L'esthétique de la dérision dans les romans de la période réaliste en France (1850-1870)», Studi Francesi [Online], 148 (XLX | I) | 2006, online dal 30 novembre 2015, consultato il 19 avril 2021. URL: http://journals.openedition.org/studifrancesi/30637 ; DOI: https:// doi.org/10.4000/studifrancesi.30637

Questo documento è stato generato automaticamente il 19 avril 2021.

\section{(c)}

Studi Francesi è distribuita con Licenza Creative Commons Attribuzione - Non commerciale - Non opere derivate 4.0 Internazionale. 


\title{
Sandrine Berthelot, L'esthétique de la dérision dans les romans de la période réaliste en France (1850-1870)
}

\author{
Cecilia Torelli
}

\section{NOTIZIA}

SANDRINE BERTHELOT, L'esthétique de la dérision dans les romans de la période réaliste en France (1850-1870), Paris, Honoré Champion, 2004, pp. 731.

1 In questo studio, ricco di approfondimenti e di riferimenti culturali, l'A. si propone di analizzare ed illustrare il realismo inteso come letteratura di derisione che, nata in opposizione ai valori borghesi del tempo e ai canoni classici, riunisce in sé il reale e il comico. Il lavoro dell'A. si sviluppa, come già indicato nel titolo, in uno spazio temporale che dal 1850, anno scelto al fine di poter prendere in considerazione i primi testi della bohème che, tra il 1847 e il 1850, appaiono nei giornali sotto forma di feuilleton, giunge fino al 1870, data che segna alcuni eventi importanti: la morte di Jules de Goncourt, il ritorno a Parigi di Victor Hugo, la pubblicazione de La Fortune des Rougon di Emile Zola ne "Le Siècle", infine la caduta del regime napoleonico. Il realismo, secondo l'A., ripropone e sviluppa in maniera nuova i procedimenti del comico, offrendo al lettore una visione deformata dell'uomo, soprattutto del borghese, verso il quale la satira assume i toni più accesi, fino ad arrivare alla caricatura, nella quale la deformazione costituisce l'origine dell'imitazione. In questo processo il comico diventa parte inscindibile del grottesco, che crea un nuovo modello di percezione della realtà, ridicola e tragica nello stesso tempo. La ricerca dell'A., che si sviluppa nella duplice direzione di un grottesco satirico e di uno metafisico, prende avvio dalla nota prefazione a Cromwell di Victor Hugo, nella quale lo scrittore definisce il grottesco nel suo aspetto comico e satirico e nella sua volontà di rappresentare il mondo dell'imperfetto e del brutto. Protagonisti fondamentali dell'espressione del grottesco sono anche Flaubert, con il suo grotesque triste, atto a cogliere la stupidità umana e a 
dare un'immagine della realtà che affianca il bello al brutto e i Goncourt, che prediligono una visione del corpo secondo gli schemi di un'estetica del basso e degli istinti. L'A. non si sofferma solo sui grandi della letteratura, ma dedica ampio spazio ad autori minori, come Murger, Champfleury, Feydeau, Duranty, Monnier, Daumier.

2 Concludono il volume una biografia scrupolosa e precisa che tocca diversi temi, un indice dei nomi e uno dei titoli, una tavola delle materie. 